\title{
Kinga Majchrzak
}

Uniwersytet Mikołaja Kopernika w Toruniu

\section{Międzypokoleniowy projekt „Przywracanie Pamięci Miastu” \\ Intergenerational project "Restoring the Memory of the City"}

Streszczenie. W artykule zaprezentowano rozważania dotyczące międzypokoleniowego projektu edukacyjno-badawczego pt. „Przywracanie Pamięci Miastu”. Projekt ten realizowany był przez Toruński Uniwersytet Trzeciego Wieku w partnerstwie z Wydziałem Nauk Pedagogicznych Uniwersytetu Mikołaja Kopernika w Toruniu w ramach programu „Patriotyzm Jutra”, który został ogłoszony przez Muzeum Historii Polski i sfinansowany przez Ministerstwo Kultury i Dziedzictwa Narodowego. Przedsięwzięcie to opierało się na koncepcji miejsc pamięci Pierre'a Nory i nowoczesnej wizji patriotyzmu, a w warstwie dydaktyczno-metodologicznej osadzone zostało w ramach badań w działaniu, co umożliwiło łączenie treści historycznych z pedagogiczną metodą ich nowoczesnego przekazu. W tekście ukazano cele i efekty projektu, a także opisano jego przebieg i podjęte w jego ramach działania.

Słowa kluczowe: miejsca pamięci, badania w działaniu, międzypokoleniowe uczenie się, kompetencje, projekt edukacyjno-badawczy.

Summary. The article presents reflections on the intergenerational educational-research project entitled "Restoring the Memory of the City". This project was carried out by the University of the Third Age in Torun in partnership with the Faculty of Education of the Nicolaus Copernicus University in Torun within the "Patriotism of Tomorrow" framework announced by the Polish History Museum and financed by the Ministry of Culture and National Heritage. This project was based on Pierre Nora's concept of memorial sites and modern vision of patriotism. In didactic-methodological layer it was embedded within the framework of action research, thereby allowing to combine historical contents with pedagogical method of their modern transfer. The text shows the objectives and results of the project. Also, it describes its course and activities undertaken throughout its duration.

Keywords: memorial sites, action research, intergenerational learning, competence, educational-research project. 
Projekt „Przywracanie Pamięci Miastu” miał charakter edukacyjno-badawczy. Było to międzypokoleniowe przedsięwzięcie, realizowane od kwietnia do grudnia 2014 roku przez Toruński Uniwersytet Trzeciego Wieku w partnerstwie z Wydziałem Nauk Pedagogicznych Uniwersytetu Mikołaja Kopernika w Toruniu w ramach programu „Patriotyzm Jutra”, który został ogłoszony przez Muzeum Historii Polski i sfinansowany przez Ministerstwo Kultury i Dziedzictwa Narodowego. Podjęte w jego ramach działania zostały objęte honorowym patronatem: Marszałka Województwa Kujawsko-Pomorskiego, Prezydenta Miasta Torunia, JM Rektora UMK, Wyższej Szkoły Filologii Hebrajskiej w Toruniu, Samorządu Doktorantów UMK, Samorządu Studentów UMK, Muzeum Okręgowego w Toruniu, Fundacji Generał Elżbiety Zawackiej, Archiwum i Muzeum Pomorskiej Armii Krajowej oraz Wojskowej Służby Kobiet, Pracowni Badań nad Pamięcią Zbiorową w Postkomunistycznej Europie (POSTCOMER), a także patronatem medialnym: Radia Gra, Polskiego Radia PiK, Radia Sfera, TV UMK, a także gazety „Teraz Toruń” i „Nowości”.

Projekt opierał się na koncepcji miejsc pamięci Pierre’a Nory (1996, 1997, 1998, 2001, 2007, 2009) oraz nowoczesnej wizji patriotyzmu, które nie ograniczają się do martyrologii, uwzględniają istnienie żywej historii, a jednocześnie dochowują wierności przodkom i służą ocaleniu znaczących wartości, idei, wzorów zachowań (Drałus, Wichłacz, 2014; Nikitorowicz 2014). W warstwie dydaktyczno-metodologicznej osadzony był w ramach badań w działaniu i łączył treści historyczne z pedagogiczną metodą ich nowoczesnego przekazu.

Przedsięwzięcie to miało na celu:

- popularyzację wiedzy na temat toruńskich miejsc (nie)pamięci, przypomnienie osób i wydarzeń, które odcisnęły ślad nie tylko na historii współczesnego grodu Kopernika, ale i Polski, a także zainspirowanie do dalszego gromadzenia informacji na ich temat;

- promowanie postaw obywatelskich i nowoczesnego patriotyzmu opierających się na subiektywnym nadawaniu znaczeń miejscom pamięci oraz działaniu w poczuciu odpowiedzialności za dobro wspólne i akceptacji szeroko rozumianej odmienności przez upowszechnianie wiedzy historycznej i znajomości polskiego dziedzictwa kulturowego na przykładzie Torunia;

- rozwijanie kompetencji społecznych, obywatelskich, interkulturowych, etnograficznych w praktycznym działaniu; 
- umożliwienie zgromadzenia doświadczeń pozwalających na wzbogacenie tożsamości o nowe elementy, konstruowanie tożsamości zbiorowej, tożsamości regionalnej;

- stworzenie płaszczyzny międzypokoleniowego dialogu opierającego się na dobrowolności i współpracy oraz dalekiego od moralizatorstwa;

- zgromadzenie materiału teoretycznego i empirycznego dotyczącego potencjału edukacyjnego (toruńskich) miejsc pamięci.

Aby możliwe było osiągnięcie wskazanych wyżej celów w czasie realizacji projektu, podjęte zostały różne działania adresowane do przedstawicieli różnych grup wiekowych - przedszkolaków, uczniów szkół różnych typów, studentów, osób pracujących, emerytów/seniorów.

Przeprowadzono międzypokoleniowe warsztaty artystyczne pt. „Portrety pamięci (miasta) $\mathrm{z}$ historią $\mathrm{w}$ tle". W czasie ich trwania dzieci z przedszkoli i szkół podstawowych, studenci UMK oraz słuchacze TUTW wysłuchali wspomnień (m.in. profesora Andrzeja Tomczaka) dotyczących Torunia i nietuzinkowych osób, które na zawsze zapisały się w historii grodu Kopernika. Mieli także okazję podzielić się własnymi refleksjami. Następnie wszyscy uczestnicy starali się wspólnie udzielić odpowiedzi na pytanie: Czy pamięć jest formą zamkniętą, czy otwartą? Dokonali wyboru koloru pamięci. Poznali technikę malowania tuszami i stworzyli kolaże techniką mieszaną.

Najlepsze prace plastyczne oraz dokumentujące ich przebieg zdjęcia można było oglądać na wędrującej wystawie, którą prezentowano w różnych obiektach Uniwersytetu Mikołaja Kopernika, w Książnicy Kopernikańskiej, Bibliotece Pedagogicznej im. gen. bryg. prof. Elżbiety Zawackiej w Toruniu, Urzędzie Miasta Toruń, Filii nr 1 Książnicy Kopernikańskiej.

Przeprowadzono międzypokoleniową grę miejska pt. „Przywracanie pamięci miejscom", którą adresowano do osób powyżej 13 roku życia. Jej organizatorami byli słuchacze TUTW i studenci UMK, którzy wspólnie opracowali trasę i zasady gry, stworzyli zadania i wskazówki dla jej uczestników, wykonali materiały dydaktyczne (plakaty i ulotki zawierające informacje o poszczególnych miejscach pamięci, postaciach i wydarzeniach, którym zostały one poświęcone) oraz przygotowali akcję promocyjną przedsięwzięcia.

Zadaniem uczestników tego przedsięwzięcia, którzy wcielili się w rolę podróżników w czasie i zostali podzieleni na maksymalnie sześcioosobowe zespoły, było odnalezienie wybranych miejsc pamięci/stanowisk zlokalizowanych na terenie toruńskiej starówki, wpisanej w szerszą perspektywę Torunia. $\mathrm{Z}$ każdym miejscem pamięci, które znajdowało się na trasie gry, wiązało się punktowane zadanie. Po jego wykonaniu - bez względu na rezultat 
- każda drużyna otrzymała wskazówkę umożliwiającą lokalizację kolejnego miejsca pamięci/stanowiska na trasie gry. O zwycięstwie w grze decydowała liczba zgromadzonych punktów, których liczbę wpisywano każdej drużynie do przygotowanych specjalnie na tę okoliczność Kart Podróży (drużyny otrzymały je na starcie gry). Aby drużyna mogła otrzymać nagrodę gwarantowaną za udział w grze, musiała wspólnie odnaleźć wszystkie miejsca pamięci/stanowiska oraz najpóźniej o godzinie 14 dotrzeć do ostatniego z nich i wykonać tam zadanie specjalne.

Przeprowadzony został również międzypokoleniowy konkurs literacki pt. „Przywracanie pamięci miejscom” na utwory literackie (wiersze, krótkie opowiadania, eseje, itp.) inspirowane toruńskimi miejscami pamięci. W jego wyniku przyznano nagrody główne i wyróżnienia w czterech kategoriach wiekowych: między 13 a 17 rokiem życia, między 18 a 25 rokiem życia, między 26 a 49 rokiem życia, powyżej 50 roku życia.

Wszystkie nagrodzone i wyróżnione w konkursie teksty zostały opublikowane w książce Alternatywny przewodnik po toruńskich miejscach pamięci, wydanej przez Wydawnictwo Naukowe UMK. Publikacja ta udostępniania jest w wersji elektronicznej na stronie: http://www.wydawnictwoumk.pl/zasoby/attachments/Alternatywny_przewodnik.pdf.

Przygotowany został także portal internetowy poświęcony toruńskim miejscom pamięci: „Toruńskie miejsca pamięci w oczach juniorów i seniorów" (http://www.tmp.umk.pl/), który może stanowić źródło inspiracji, m.in. dla nauczycieli chcących przeprowadzić alternatywne lekcje historii dotyczące Torunia. Na platformie tej upowszechniono różnorodne materiały dydaktyczne, które powstały w czasie realizacji projektu, w tym przykładowe scenariusze zajęć. Zamieszczono tam dokumentujące przebieg projektu zdjęcia, wszystkie prace powstałe w czasie trwania międzypokoleniowych warsztatów artystycznych „Portrety pamięci (miasta) z historią w tle”, link do elektronicznej wersji „Alternatywnego przewodnika po toruńskich miejscach pamięci". Co ważne, za pośrednictwem prezentowanego serwisu internetowego zainteresowane osoby mogą dzielić się z innymi materiałami, przemyśleniami czy odczuciami dotyczącymi (toruńskich) miejsc pamięci.

Dnia 9 grudnia 2014 roku odbyło się seminarium poświęcone projektowi „Przywracanie Pamięci Miastu”, w czasie którego wręczono nagrody laureatom międzypokoleniowego konkursu literackiego „Przywracanie pamięci miejscom” oraz zaprezentowano Alternatywny przewodnik po torunskich miejscach pamięci i portal internetowy „Toruńskie miejsca pamięci w oczach juniorów i seniorów". W organizację seminarium zaangażowana była Pracownia Badań nad Pamięcią Zbiorową w Postkomunistycznej Euro- 
pie (POSTCOMER), reprezentowana przez dr. Rigelsa Halilli, który w czasie jego trwania wygłosił referat pt. „Pamięć zbiorowa, historia, polityka”.

Efektywna realizacja projektu „Przywracanie Pamięci Miastu” nie byłaby możliwa bez zaangażowania słuchaczy TUTW i wolontariuszy z kół naukowych WNP UMK i WNH UMK, a także bez prowadzonych na wszystkich etapach jego realizacji konsultacji z pracownikami naukowo-dydaktycznymi WNP UMK i WNH UMK.

Analiza materiału empirycznego powstałego w czasie trwania projektu (zdjęć i filmów, kalendarzy i esejów autorstwa osób zaangażowanych w jego realizację, ankiet ewaluacyjnych) pozwala wnioskować, że był on dla jego uczestników nie tylko ciekawą formą spędzenia wolnego czasu, ale także cenną lekcją historii. Potwierdza również tezę, że dzięki zastosowaniu metodologii opierającej się na praxis można wydobyć potencjał edukacyjny miejsc pamięci. Uzmysławia także, że dzięki wykorzystaniu metod aktywizujących opartych na pracy zespołowej, jak np. organizacja gier miejskich i uczestnictwo w nich, możliwe jest: uczenie się siebie i od innych, gromadzenie doświadczeń pozwalających na wzbogacenie tożsamości o nowe elementy, a także konstruowanie kompetencji, tj. zdolności krytycznej oceny informacji oraz ich uzyskiwania i wykorzystywania, myślenia przyczynowo-skutkowego, oceny własnego zaangażowania, podejmowania decyzji, efektywnego komunikowania się z innymi, współpracy, promowania interesów własnych i grupy, definiowania swoich celów czy akceptacji szeroko rozumianej odmienności. Utwierdza ponadto w przekonaniu, że tego typu działania edukacyjne pozwalają na uczenie się w działaniu, a przede wszystkim są płaszczyzną uczenia się międzypokoleniowego, które cechuje wielokierunkowość i wzajemność, gdyż w czasie ich trwania uczą się od siebie wszystkie podmioty procesu dydaktycznego. Po przeprowadzeniu projektu można stwierdzić, że miejsca pamięci stanowią znakomity impuls do pozbawionego moralizatorstwa dialogu między osobami w różnym wieku. Są obszarem stanowiącym tzw. punkt wspólny, który sprawia, że reprezentanci różnych pokoleń chcą razem spędzić czas, działać w celu osiągnięcia ważnej społecznie zmiany.

\section{Bibliografia}

Drałus D., Wichłacz M (red.) (2014), Nowoczesne formy patriotyzmu i nacjonalizmu w kontekście przemian wspótczesnych systemów społeczno-politycznych, Wrocław. 
Nikitorowicz J. (2014), Patriotyzm i nacjonalizm. Ku jakiej tożsamości kulturowej?, Kraków.

Nora P. (2001), Czas pamięci, „Res Publica Nowa”, nr 7.

Nora P. (2009), Między pamięciq i historią: Les lieux de Memoire, „Tytuł Roboczy. Archiwum", nr 2.

Nora P. (red.) (1996), Realms of memory: the construction of the French past, T. 1: Conflicts and divisions, New York.

Nora P. (red.) (1997), Realms of memory: the construction of the French past, T. 2: Traditions, New York.

Nora P. (red.) (1998), Realms of memory: the construction of the French past, T. 3: Symbols, New York.

Nora P. (2007), W poszukiwaniu europejskich miejsc pamięci, „Borussia. Kultura. Historia. Literatura", nr 41. 